821.111.09-31 Swift G.

https://doi.org/10.18485/bells.2019.11.11

\author{
Bojana Gledić* \\ University of Belgrade \\ Faculty of Philology \\ Belgrade, Serbia
}

\title{
FACES OF EMPIRE IN GRAHAM SWIFT'S WATERLAND
}

\begin{abstract}
Aside from being Graham Swift's most famous piece of writing and probably one of the most praised British novels of the 1980s, Waterland is considered by many critics to be the embodiment of the postmodernist novel. Linda Hutcheon used it as an example to illustrate what she defined as "historical metafiction" and when one thinks of Waterland it is usually in connection with history and the role it plays in the life of ordinary people. It is interesting how, at first glance, the particular kind of history Graham Swift is addressing in this novel seems to escape both reader and critic. On further investigation, however, what does not escape is the underlying presence of Empire in the novel, which is the reason why this paper examines its versatile role in Tom Crick's version of history.
\end{abstract}

Keywords: Waterland, Empire, Graham Swift, postcolonial, postmodern

\section{Introduction: Waterland in the Network of Interpretations}

When one thinks about Graham Swift, it is difficult to decide whether to categorize him as a modernist or postmodernist author. Critics who engage in reviewing and investigating Swift's work do not always agree on this point, which has remained moot for several decades (just to give a couple

\footnotetext{
E-mail address: bojana.gledic@fil.bg.ac.rs; bojanadgledic@gmail.com
} 
of examples, in their respective studies of contemporary British fiction, Malcolm Bradbury would identify Swift as a modernist author (Bradbury 2001: 6) while Nick Bentley would categorize him as postmodernist (Bentley 2008:31)). Swift's complex work can definitely be interpreted from these two different standpoints, but the most challenging one is perhaps to study it within postcolonial discourse, an endeavour which we have undertaken (Gledić 2016; 2018). However, aside from adding the postcolonial aspect of his work to the aforementioned binary list, we are more inclined to agree with those authors who would not define Swift as a postmodernist author, but still recognize such elements in his work (some examples of like-minded scholars interested in Swift would be Daniel Lea and Peter Widdowson who are in agreement with this view in their studies on the author (Lea 2005: 4, Widdowson 2006: 4-6) or Catherine Bernard who categorizes Swift's style as quietly rebellious, resembling the waters of the Fens. (Bernard 1991: 8)).

In her ground-breaking work on postmodernism, Linda Hutcheon declared the former "centre" a thing of the past and stated that "our culture is not really the homogenous monolith (that is middleclass, male, heterosexual, white, western) we might have assumed". (Hutcheon 1988: 12) This, naturally, implied a re-evaluation of the past as presented to a modern-day audience and Hutcheon assessed the issue of the past in contemporary postmodernist literature. In a way, she propelled Graham Swift into the spotlight of postmodernism by including the example of Waterland in her definition of it (Swift's work has also been discussed as falling in line with Brian McHale's postmodernist theory as expressed in Postmodernist Fiction (Tollance 2011: 109)). Historiographic metafiction, which Graham Swift makes use of in this novel, is, according to Hutcheon, a very important aspect of postmodernism, it proves its connection to history and denies claims of it being dehistoricized or ahistorical. (1991: 57) In her discussion on Waterland, Hutcheon states that "What historiographic metafictions like Waterland or I the Supreme ask, as we have seen, is whether the historian discovers or invents the totalizing narrative form or model used." (1991: 64) The unreliability of both the source and the content are what Swift himself addressed in Waterland, but along with this he presents the stand that learning, teaching and acknowledging history is both obligatory and essential:

... history is that impossible thing: the attempt to give an account, with incomplete knowledge, of actions themselves undertaken 
with incomplete knowledge. So that it teaches us no short-cuts to Salvation, no recipe for a New World, only the dogged and patient art of making do. I taught you that by for ever attempting to explain we may come, not to an Explanation, but to a knowledge of the limits of our power to explain. Yes, yes, the past gets in the way; it trips us up, bogs us down; it complicates, makes difficult. But to ignore this is folly, because, above all, what history teaches us is to avoid illusion and make-believe, to lay aside dreams, moonshine, cure-alls, wonder-workings, pie-in-the-sky - to be realistic. (Swift 1984: 94)

This, certainly, is what is reflected in the "real world" we populate as we have frequently asked ourselves, within these past decades, whether all of history is just a story, and "his" story at that. However, one should never forget that even though it all may indeed be just a story, we should try to get to the bottom of it, to explore it, to see what is missing in it, to find all its different versions.

\section{Waterland in the Chains of History}

We are of the opinion, and in this we join Waterland's main protagonist Tom Crick, that to ignore history or to cast it aside as pure fabrication would be a mistake. In Hutcheon's opinion, postmodernism suggests "no search for transcendent timeless meaning, but rather a re-evaluation of and a dialogue with the past in the light of the present". (Hutcheon 1988: 19) Furthermore, postmodernism "does not deny the existence of the past; it does question whether we can ever know the past other than through its textualized remains". (Hutcheon 1988: 20) Consequently, postmodernism calls for all voices to be heard. As if following the same line of thought, Tom Crick keeps asking himself throughout Waterland whether history is nothing but another story. As a history teacher, he relies on stories to teach his students, but at some point he starts telling them random stories that have nothing to do with "real history" and it becomes hard for the reader to discern what the actual "truth" of it all is. During this endeavour, we encounter one of Tom's students, a boy named Price, who is fixated on the present and thinks that instead of being focused on things past, history classes should dwell on issues in connection with "Afghanistan, Iran, Northern Ireland, the ills of this worn-out Great Britain of ours." (Swift 
1984: 143) With this character, Swift presented Crick with an opponent in the battle on the meaning of history, but not in the form of Crick's superiors, who want to abolish the school subject of history, but as part of a new generation, the one that will inherit the world from the likes of Crick and his ancestors. Price is the founding president of "The Holocaust Club - the Anti-Armageddon League" and Crick holds that Price's pessimistic view of the future is nothing new, it is the feeling that Saxon hermits felt, that the people who built the pyramids felt, that Crick's father and grandfather felt, that Mary felt: "It's the old, old feeling, that everything might amount to nothing." (Swift 1984: 233) Regardless of this fact, Crick does not seem to believe that it was his generation's responsibility to save the next one. (Swift 1984: 223) He understands Price's concerns, but holds his ground when matters of history are concerned, because "we move in circles" (Swift 1984: 118), not knowing where salvation lies, and no one can really know which way to turn. Crick is painfully aware of the fact that history causes us to advance and retreat, but one should not let go of it all the same. Furthermore, although he grew up in a place where "nothing is hidden from God" (Swift 1984: 248) with the coming of adulthood he abandoned the idea of a higher might and guiding force (Swift 1984: 203-204; 232) so there is nothing else to comfort him but his own never-ending curiosity and inquisitiveness.

What Waterland undoubtedly seems to illustrate is that personal stories contribute to our perception of history as much as an official account does. This would again draw our attention to the voices unheard and it could be argued that Tom Crick has articulated this new approach to history in the postmodern text. (Jovanović 2012: 194-195) In the words of Linda Hutcheon: "Tom Crick is in some ways an allegorical representation of the postmodern historian who might well have read, not just Colingwood, with his view of the historian as storyteller and detective, but also Hayden White, Dominick La Capra, Raymond Williams, Michel Foucault, and JeanFrançois Lyotard." (1991: 56) Tom appears to have been infected with all the contemporary ailments of pessimism: "And there's no saying what heady potions we won't concoct, what meanings, myths, manias we won't imbibe in order to convince ourselves that reality is not an empty vessel." (Swift 1984: 35) Furthermore, when compared to history, which has proven to be a constant companion, "... the Here and Now, which brings both joy and terror, comes but rarely - does not come even when we call it. That's the way it is: life includes a lot of empty space. We are one-tenth living tissue, 
nine-tenths water; life is one-tenth Here and Now, nine-tenths a history lesson. For most of the time the Here and Now is neither now nor here." (Swift 1984: 52) Adding the aforementioned moving in circles, Tom's view of the world and people's place in it appears sombre, although he keeps pushing history to the foreground as a virtual life jacket. In attempting to save his own life by recounting his personal history, Tom occasionally loses his way in being temperate and objective. For this reason, he may appear to the reader to be unjustifiably taking up space in the novel, playing the role of the be-all and end-all of his own personal quest for answers. In the words of Pamela Cooper: "Although Tom-as a contemporary version of (a fictional representation of) a Victorian entrepreneur-works into his story a provisionality and doubt which question the stability even of narrative itself, he clearly admires the imperialist values of his ancestors". (1996: 378) Tom's narrative style is so dominating that his dedication to history and pursuit of curiosity have been deemed "essentially imperialistic" (Lea 2005: 91), he "silences women's histories" in the story (Orr 2016: 86), he is the "star" of his own show (Bernard 1991:101) and his story pervades over the past "like the Atkinsons did over the Fens". (Meneses 2017: 140)

In the realm of postmodernism, where history is viewed in a new light, chapters that used to be considered closed are being reopened and re-examined. Still, as our access to history is "conditioned by textuality" (Hutcheon 1988: 16) one cannot escape the painful fact that every document ever written in the course of history was written by someone who at a certain point of time had their own fence of circumstances and personal point of view. There can be no "unpositioned centre" (Jenkins 2009: 82) from which one can view history and "we only have representations of the past from which to construct our narratives or explanations" and even though the past did exist, it "exists for us - now - only as traces on and in the present." (Hutcheon 1991: 58; 73) We deal with traces that have been left as such, and those that were always written from a certain point of view. No account is ever unbiased, and it is for this very reason that Hayden White equates the historian with the storyteller. (1978: 82) Historians can be viewed as individuals who have chosen certain elements and presented them from their own point of view. Every individual adds a certain nuance to their own version of the past. This stems from people's personal obsessive relationship with the past that never leaves them; as William Faulkner put it: "... time is a fluid condition which has no existence except in the momentary avatars of individual people. There is no such thing as was 
- only is. If was existed, there would be no grief or sorrow." (Cowley 1965: 141) Tom Crick is achingly aware of this fact, and throughout the novel he mentions it several times, first in connection with his mother's death: "And though, indeed, it only happened once, it's gone on happening, the way unique and momentous things do, for ever and ever, as long as there's a memory for them to happen in ..." (Swift 1984: 237-238) and "Yet it is as it was, was as it is. Iswas. It's the past! What stops but remains." (Swift 1984: 273), and then in the context of losing what he believes is his unborn child: "But then we've already stepped into a different world. The one where things come to a stop; the one where the past will go on happening... ... We'll be here for ever." (Swift 1984: 263) In order to cope with the passing of time, people are forced to compartmentalize the feelings and experiences from their personal pasts. It could be that the selective view of collective or national history stems from this necessity, in addition to it being intentional at times.

In the context of Graham Swift's novels, the storylines of which heavily rely on the past and its role in people's lives, it is of vital importance to take into account what kind of history paved the way for any kind of activity that takes place in them. The lives of characters whose ancestors lived in the disputably glorious time of the British Empire cannot be viewed in the same light as we would view, for example, characters who belong to nations that used to be colonized or oppressed in any other way. Neither can it be said that Swift is an active critic of imperial policy, as the main focus of his novels is not open criticism of such a societal structure and idea of progress, but it is in the subtlety of his descriptions where one can find, if one looks carefully enough, mild but visible criticism of all that Great Britain used to stand for in the course of the centuries preceding the time frame of his novels. According to Hutcheon, Waterland is "a didactic fictive lesson or a meditation on history - or both. No historical characters populate this book, but it is a profoundly historical work none the less, in both form and content." (1991: 54) The "real" history is constantly interlaced with Tom's and other characters' personal stories: "Imperial myths and yarns, ghost stories, narratives of progress, and delusions can all be contrasted with material facts and counter narratives of failure. The grand narrative of British glory and progress ends in the failures of the 1940s. ... But in all this, it should be noted that these illusions and these yarns have effects. They shape history, events, and actions just as reality does." (Malcolm 2003: 93) Taking into account all the above said, imperialism will play a pivotal role in reconstructing the history of this novel and its characters. 


\section{Empire on the Stage}

As Waterland's story spans several centuries, one should fully acknowledge the fact that the British Empire and its imperial policy will be part of the package that we call "history" in this novel. Consequently, it is inevitable that we try to treat this novel in the light of postcolonial theory, in addition to the postmodern aspect. With the aim of taking into account all the various bits of the "whole story", it is the role that Empire plays in Swift's work that we find particularly interesting and worthy of closer examination. To Hutcheon's suggestion that, in Waterland, "[i]n the opposition between the history-teacher narrator and his present-oriented students are enacted the conflicts of contemporary historiographic debate" (1991: 72) we would add that this opposition also reflects the changes that have come about in British society after the disillusionment the end of Empire brought to Great Britain. It is this sense of disillusionment and reflections on the British nation as a whole that various Swift scholars have noted in their studies of him. For example, Daniel Lea wrote that Swift's “... abiding diagnosis of British society in the second half of the century is of a chronic melancholia that mourns the lost stabilities of the past with a lachrymose nostalgia. The sense of dislocation and alienation that bedevils the subject springs from a systemic abandonment of institutional authority and its replacement by an ideological and ethical free-for-all that champions its democratic relativism even as it disavows collective responsibility." (2005: 10-11) Pamela Cooper compared Swift's Waterland and Last Orders with Kazuo Ishiguro's The Remains of the Day in the sense that they depict "... a postwar British society in which the power of empire has dwindled and the country's historical mission is profoundly unclear" (2002: 19) and we presented, as part of our $\mathrm{PhD}$ research, how most of Swift's novels could be interpreted within the postcolonial discourse (Gledić 2018). Furthermore, Stef Craps noticed that "At one level, Swift's novels can be read as 'condition of England' novels." (2005: 18) and David Malcolm states that "... throughout Swift's fiction, one has a sense that he is describing and discussing aspects of the nation". (2003: 21)

When we interpreted the work of Graham Swift in the postcolonial discourse, one of our main points was that he was an author living and writing in a postcolonial Great Britain. We are of the opinion that, in addition to every historical document being written under certain circumstances and from a certain point of view this is also true of novelists and other 
artists - they are always influenced by the moment in time in which they are creating. As Edward Said put it: "I do not believe that authors are mechanically determined by ideology, class, or economic history, but authors are, I also believe, very much in the history of their societies, shaping and shaped by that history and their social experience in different measure." (1994: xxiv) The end of Empire in the wake of which Graham Swift was born has to have had a deep impact on his formative years, as a person and as a novelist. Great writers always seem to be more deeply aware of their surroundings than everyone else, so the overall sense of disillusionment probably did not escape him. Yet, however talented, every artist is still human, and people "cannot avoid representation". (Hutcheon 1991: 54) What could be categorized as a drawback in Swift's overall work - the absence of a more "realistic" view of contemporary British society - could in fact be the representation of a certain segment of British society the world of which looks exactly as it is described. Graham Swift himself has said that "It's true that in a fundamental sense all fiction writing is autobiographical, since where else does it come from but from within the author?" (2009: 1) and when discussing one of Swift's other novels, Last Orders, one critic noticed that the world as presented in Swift's fiction is the world his narrators would see. (Malcolm 2003: 19) Waterland falls under this category in its failure to openly address the pressing issues of the British colonial era and its legacy.

Great Britain, as a country and a nation, has changed a lot during this past century. The disappearance of the spirit of imperialism, along with other, minor factors, was the driving force behind this change. After the Second World War and the end of Empire, it was necessary to re-awaken a renewed sense of the nation. As Stuart Hall put it, "National cultures construct identities by producing meanings about "the nation" with which we can identify; these are contained in the stories which are told about it, memories which connect its present with its past, and images which are constructed of it." (Hall 2000: 613) The construction of English identity is visible in the stories of Tom Crick, and the story of some of his ancestors and their fellow countrymen in a way tell the story of England (or Britain) itself. Nevertheless, and in spite of the abundance of stories that Waterland presents, it is in the untold stories of this novel that we look for the attitude toward Britain's questionable past. The silence in Waterland has been recognized as one of the key elements of the novel's impact on the reader and the value of the novel as a whole (Bernard 1991: 108), the silence can 
be interpreted as an anti-narrative which stops Tom Crick from being in fact what he is speaking against (Meneses 2017: 147) and it can also be viewed as an act of resistance, as unhappening is also a form of happening. (Orr 2016: 92) We have already mentioned that certain scholars who interpret the work of Graham Swift find Waterland's main protagonist too dominating and/or egocentric, and this is an additional reason why it is useful to carefully inspect what is not being said in the novel.

According to Graham Swift himself, Waterland "among other things, deals with nostalgic, grandiose notions about British power, empire, influence in the world". (Craps 2009: 642) Throughout the novel "hints of a national dimension to the action continually intrude" and the history presented throughout the novel resembles that which is taught in history books. (Malcolm 2003: 79; 103-109) Perhaps the best connection of Waterland and postcoloniality is presented in Pamela Cooper's paper on Waterland, in which she states: "Written in the aftermath of empire and selfconsciously enmeshed with its legacies, Waterland engages the colonialist motifs of propulsion and escape with the aggrieved, derisive passion of a postcoloniality enthralled by the imperialism it critiques.". Furthermore, "In Waterland, as so frequently in postcolonial literature, the processes of psychic individuation effectively model the trajectory of imperialist enterprise-with its dynamic of conquest, its imagery of borders and migration, its hallucinatory anxiety about contact and separation." (1996: 372-373) Associating Waterland with postcolonialism is not so frequent among scholars, although it was interesting to find that one scholar interpreted Swift in light of the Commonwealth of Nations and new trends in literature inspired by a wish to engage in an attempt to transcend a past that oppresses and requires self-reflection, using an inward glance. According to this author, Graham Swift's novel is the complete opposite of other novels written at the same point in time which expressed longing and nostalgia for the Raj. (Jain 2010) We share the opinion that Swift is not nostalgic in terms of Great Britain's colonial past, but it is definitely there, in the novel's charged silences.

\section{The Many Faces of Empire}

When we interpreted almost the entire opus of Graham Swift within postcolonial discourse as part of our research (Gledić 2018), these were 
some of our most prominent findings of postcolonial elements in this novel (we did not dwell on the fact that Tom Crick is perhaps an imperialist at heart): When Tom Crick was a boy, he read the literature typical for the peak of the colonial period - G. A. Henty's novel With Clive in India, books that contained a certain amount of propaganda placed in popular reading materials. In her cottage, which will be a place of doom for Tom and Mary, Martha Clay keeps a yellowed newspaper clipping photograph of Winston Churchill. (Swift 1984: 263) When Tom talks about land reclamation, he equates the conquering of land in the East Fens with the British Empire because the zenith is where decline begins. (Swift 1984: 80) In chapter 49, titled "About Empire-building" Tom warns his students that taking back land, reclaiming what was lost, is a model of progress that should not be confused with the building of empires. (Swift 1984: 291) Tom refers to Empire as a fairy tale, one which his contemporaries are ashamed of, and during his childhood Empire Day was celebrated with enthusiasm, but so is Bastille Day in France. (Swift 1984: 155-156) The last quarter of the nineteenth century, and the subsequent rule of King Edward, respectively labelled as prosperous and dear in collective memory, Tom holds to be a period of economic deterioration that England never recovered from. (Swift 1984: 137) When Tom talks about his pupils, we get a glimpse of the multicultural society Great Britain has become after the fall of Empire Tom mentions Judy Dobson and Gita Khan. (Swift 1984: 168) Perhaps the most notable mentions of Empire in Waterland are those connected with the Atkinson family, and this is a connection most papers on Waterland deal with. Progress is equated with Empire, and the Atkinsons piously follow the idea of progress. Beer from the Atkinson brewery was sent to Bombay, for the British soldiers to drink, and it was called "Atkinson India Ale". (Swift 1984: 79) The Atkinsons paid their debt to the Empire by opening numerous establishments, like an orphanage, a town newspaper, a public meeting-hall, a boys' school, a bath-house, a fire station. As a private empire, they paid their dues with regards to the National Interest. Their beers were frequently named in honour of Empire: "The Grand '51", "The Empress of India", "The Golden Jubilee", "The Diamond Jubilee". (Swift 1984: 80) This does not come as an unusual fact to the reader because Arthur Atkinson is presented as a big supporter of imperialism and imperial policy. (Swift 1984: 90) Tom tells his students that Arthur did not know what disappointment the Victorian Age would bring, and the early twentieth century brought only loss and regret with regards to Arthur 
Atkinson's "confident sentiments". (Swift 1984: 81) Arthur's son Ernest was not of the same opinion as his father. He was an avid opponent of building the Empire and praising the progress of Great Britain. (Swift 1984: 186) Sarah Atkinson, who seems to have foreseen numerous events, according to the narrator may also have predicted the end of Empire because he views her as resembling the figure of an intrepid Britannia, with a helmet, trident and shield, sitting on a sea-girt rock and staring in an unknown direction. (Swift 1984: 81)

After more detailed consideration of these findings, which was not part of the initial round of research, more possible interpretations emerged - the seemingly imperialistic plot of Waterland might, in fact, be interpreted as subdued criticism of Empire. In this sense, the face of the British Empire is present in different forms in the novel and its role is versatile. The abandonment of a grand narrative implies the abandonment of any straightforward tale of Empire, and even though Waterland describes, in minute detail, the eternal conflict between the land (the solid soil on which Empire rests, represented by the Atkinsons) and the water (the muddy whirlpool that benefits no one, represented by the Cricks) it could be that the tale of Empire is in fact contained in the untold story of Waterland. If it is not the land, but the water that symbolizes Empire, what seems like chaos and disorder could in fact be the underlying state of affairs which is always there, lurking in dark waters, waiting to return. The water occasionally rises, as does the desire to rule, it drowns everything in its wake, but it is forced to return where it came from, only to get ready for the next wave of attacks. When the Empire retreats, the land goes back to the people. In this sense, Waterland could be another name for Great Britain because Great Britain will forever be connected to the great Empire it once was.

Waterland could be interpreted as a novel about everyone; as one critic noticed, the names of three important protagonists are Tom, Dick and Harry (Gallix 2003: 84) as in "every or any Tom, Dick and Harry, anyone, indiscriminately" as the saying goes. And if it truly is so, as this same critic writes, that like Conrad's Marlow, Tom remains in the shadows so that we can get a better look at the other characters (82), then it is precisely those characters who are on the margins that carry this possible hidden meaning the novel could hold. One face of Empire could be that of Dick who, according to Daniel Lea is "trapped between the past and the future", and is "a hybrid" because he is not completely "human". (2005: 
90) According to the same author, Dick also "personifies the instinct to flow backwards". (2005: 90) We would agree to a certain extent with both statements from the former sentence, but not the latter one. Dick is indeed a hybrid, and trapped between yesterday and tomorrow, but not for the reasons stated in this study; we believe that he is a symbolic product of both worlds, the world of Empire and that of "regular folk" and that his way of communicating is unintelligible for many because he is the keeper of secrets and the key to a different world. In our opinion he is not flowing forwards because he is a constant reminder that the idea of Empire will never die. This could further be illustrated by John Schad's equating Dick with "posthistorical 'Nostalgia"' which is "Too Big' for the hole or void that is the novel's postmodern world". (1992: 912)

Dick is a silent presence for most - Tom, the little man, the regular person, confronts him and reminds him what he is a product of. The little people may not always win, but sometimes they see reality in a different way. In this sense, Tom would be one of those people who could have predicted the inevitable end of Empire and colonial policies. Dick could also be the face of Empire because, even though he does not talk, he has a hidden message, which is obvious because he speaks to his motorcycle. This could be just a coincidence, were it not for the fact that when Dick disappears at the end of the novel it is this very same motorcycle that remains behind like a silent, haunting presence the wheels of which will keep on turning, even though someone else will be riding it. Dick, though interpreted by the regular folk as someone not quite normal, could in fact be the indecipherable policies and stands which were the product of a few men which then took root in the masses. Even though Dick is described as mentally challenged, his brother is forbidden to help him, which would be very strange were it not for the fact that Dick is practically deified through this act (in addition to repeatedly being referred to as "the saviour of the world", which equates him with God or Jesus Christ). His real name, Richard (the middle name of his biological father), perhaps resonates as that of Richard the Lionheart or other great English kings, while his nickname, even though usually interpreted as pertaining to his sexuality, could perhaps be indicative of all the qualities a phallic symbol carries with it - manhood, power, courage, strength. The past, conveniently locked in a chest, belongs to Dick and Dick is the only one who has a key. At the end of the novel, Dick disappears, and one cannot be certain what has happened to him. Perhaps one might conclude that, as a face of Empire, Dick could 
not live in isolation, misunderstood, so he disappears, symbolically taking the Empire with him, but it is still in the waters, it is all around, but it is elusive. François Gallix compared Dick's disappearance in the deep waters of the Ouse with Arthurian legends about the return of the King (2003: 96), but it could also imply the dateless but certain return of Empire.

When examining the opus of Graham Swift as a whole, one can claim with certainty that female characters in his works are depicted in less detail and are smaller in number than their male counterparts. However, even though their roles are often small, they are quite memorable. The women in Waterland follow this pattern. A few papers have been written in connection with Waterland's female character's and they are connected to suspected misogyny and unfair treatment of the female body. But what if those characters, like Dick's silence, carry within them a certain undercurrent of power? What if the women of Waterland too can be viewed as the faces of Empire? Let us start with Sarah Atkinson, the beautiful wife of Thomas Atkinson, who on that fateful night of 1820 suffers a blow to the head which renders her speechless and virtually unconscious. She lives to be over ninety years old, but she spends more than half a century sitting in the same place, in the same blue velvet chair in the upper room of the family home, looking through the window, watching over Water Street, "keeping her watch over Nothing". (Swift 1984: 78) Her husband will die still trying to speak to her but without success. But what if Sarah was the essential notion of Empire which got hit in the face? What if the idea of a truly great Great Britain was betrayed by the personal interests of certain individuals? Individuals like Thomas Atkinson. Thomas Atkinson and his peers could be viewed as having betrayed the basic idea of Empire which did become warped by the beginning of the nineteenth century. In this sense, just like Dick, Sarah could be perceived as representing Empire, but also God in the shape of a woman. She is a merciless judge and she can see the future. Like a deity, she seems to control the waters because after her death floods arise and rain keeps pouring for days. In these floods, Arthur Atkinson's heir Ernest Atkinson is born, the man who will be a herald of change as far as the attitude towards Empire is concerned. After the floods, Atkinson beer will never be the same, and the aforementioned heir was born three weeks premature, prompting us to think that the waters of history called him to join them. In Catherine Bernard's interview with Graham Swift, she mentions Sarah Atkinson who "embodies a kind of grotesque allegory of England" (Morel 1996: 11) but we would dare to 
venture beyond the grotesque and see in Sarah, just as we do in Dick, one of the many faces of Empire.

Ernest Atkinson, born in the floods of 1874, will be the complete opposite of his grand ancestors, and people generally did not approve of him. (Swift 1984: 140-141) Ernest shied away from politics and after the brewery burnt down on Coronation Day in 1911 Ernest slowly withdrew from public life, leaving Gildsey altogether in 1914. This, coincidentally, corresponds with the beginning of the First World War which Ernest was strongly opposed to. During the war, Ernest makes only one, fateful, public appearance with his daughter during a military parade in the spring of 1915. The parade could not be carried out because of the commotion his daughter Helen's beauty caused. The story turns incestuous from this point - the father falls in love with his daughter and begets a son who he believes will be "the Saviour of the World". (Swift 1984: 197) Pamela Cooper holds that: "In Ernest's regressive passion for Helen the trajectory of imperialism is reversed; its expansive energies are redirected towards an interior space of desire, neither subjective nor objective, but abject: the body of the daughter. ... this redirection aborts the narrative of selfconsistent individuation which shapes the plot of imperialism." (1996: 380381) But what if Ernest Atkinson's genuine love for Britain is embodied in his love for Helen? What if Helen is all the forgotten beauty of a once great country, and imperialism in its purest form is what he is striving towards? What if he was hoping that by begetting a son, he would save what once was sacred and unmarred? After all, Ernest had a special relationship with his heritage, he could drink the Atkinsons' famed beer and not get drunk. (Swift 1984: 186) He initially appeared to be the most sober and reasonable one in all his family. However, the original idea of Empire appears to have turned in on itself in the figure of Ernest Atkinson and he himself seems to have foreseen its end, killing himself and leaving his son a farewell letter in which it is evident that he has his misgivings about beauty and Empire (in it he tells Dick that he should not have children but that this is of no importance because he will save the world (Swift 1984: 279-280)).

Almost like a commodity which belongs to everyone, Helen will be passed on from the Atkinsons to the Cricks, moving from one class to another, from a rich house to a poor one, keeping her kindness and her poise in the process. She will bring up her sons by telling them beautiful stories and she will maintain her special relationship with her firstborn. Henry Crick's very existence seems to depend on this beautiful woman 
who once again, like a powerful deity, rules the household like a silent force to be reckoned with. Like the Empire, Helen was beautiful but she perished and following her death her husband will cut ties with national identity - he will claim not to remember anything about the war that he took part in. For his part, Henry produces a son who questions History while Helen will be the last to speak to her special son, giving him the key to his (grand)father's chest and with it the key to the past. This chest, containing some of history's well-kept secrets, will disappear in another episode of epic flooding which will take place in 1947 and also claim the life of Henry Crick. The lock keeper's cottage will also disappear and the dam which was a guard against the intrusion of history will become a thing of the past.

The third important female character in the book, and perhaps the most memorable one, is Mary Metcalf, Tom Crick's childhood neighbour and friend whom he subsequently marries and takes to London to be his life companion. Mary and the little gang of friends, who had fun in their little corner of the world while a war was raging in other parts of Great Britain and Europe, are of vital importance to the story's core. Freddie Parr, Tom's neighbour, could be considered an ordinary boy, Dick, Tom's brother, was different and special in every way, while Tom was somewhere in between, neither here nor there, neither plain nor special. As one of the little people, Freddie played no role in the workings of Empire, and the baby Mary carried was most probably not his. He lost his life, presumably at the hands of Dick, but this could perhaps have been an imaginary scenario Tom had come up with due to the fear and jealousy he felt with regards to his older brother. He was both afraid of him and unable to understand him, so the story of Dick being a murderer could have been nothing but a fabrication. Additionally, since we never really find out who the father of Mary's unborn baby was, Mary's story about her telling Dick that Freddie was the father of her baby could also have been a lie. But, if that scenario did indeed happen, perhaps Empire killed the little man. On the other hand, even though Tom is not as special as Dick, and has no secret undertakings, he still does play his role in the realm of Empire by taking up the space of the novel and of the main character in the story, which becomes His-story. He and Mary both grow up without a mother, which could be taken to mean both their literal, biological mother, and their motherland which experienced the beginnings of its end as Tom and Mary reached their formative years. Mary's baby, whose father we cannot 
be certain of, could be taken to mean the future of Great Britain as a great imperial force. While Tom and Mary are walking towards the secluded hut, planes are flying to Germany on their newest bombing spree. Mary's baby meets its end in Martha Clay's hut, adorned by a yellowed newspaper clipping with a photograph of Winston Churchill. And even though Tom is instructed to stay outside, he stumbles into the cottage mid-procedure and looks in the pail at the remains of the dead foetus, realizing that is what the future looks like. Mary's very name lends her the echo of sacredness, presents her as the Holy Mother of God. She attends school in a convent, she is educated by nuns, when she attempts to kidnap a baby in later life Tom describes her as resembling the Holy Mother. She too is mystified, when she disappears after the abortion of her baby, nobody knows how she spent her time, not even her husband. There is a chance that she was visited by Sarah Atkinson, which would imply a secret bond between the women in Waterland (Mary will also be the one to nurse Tom's father after the death of his wife Helen). Women are often presented as mysterious in Swift's fiction, but in this novel perhaps even more so. In the course of her lifetime, Mary loses not one, but two babies, one biological and one imaginary, which was never hers to begin with. If we follow Mary's life story, with the thirty-six years in between the two incidents, it becomes obvious that there will be no Second Coming. All her attempts to bear a child are futile, and if she can be viewed as a face of Empire her role would be to present its barrenness, she cannot give her husband (a man who questions history) what he needs and she is empty.

\section{Conclusion: Empire as a Silent Presence}

What we have presented could be but a few possible postcolonial readings of the role of Empire in Waterland. In the character of Dick, it is puzzling, mysterious, out of reach, inarticulate, but on the other hand loyal, passionate, hard-working, persistent. In the character of Sarah it is mysterious, dominating, foreboding, unforgiving. In Helen, it is beautiful, innocent, eloquent, mesmerising. In Mary, it is both smart and naive, both knowing and innocent, both lively and barren. In Waterland, Empire takes on many forms to show just how versatile and complicated the idea of it can be. The author, like the reader, seems to have a love-hate relationship with it. This all falls in line with the political aspect of postmodernism, as 
viewed by Linda Hutcheon: “...it (postmodernism) is certainly political, but it is politically ambivalent, doubly encoded as both complicity and critique, so that it can be (and has been) recuperated by both the left and the right, each ignoring half of that double coding." (1991: 168) Adding postcolonial discourse into the study of Waterland allows us to see the entire picture. This novel can sweep over the reader with its overwhelming tales of progress and doubt, and at the next minute it can retreat into the horizon, not promising to ever come back. The role Empire plays is similar - one minute it enthrals readers with its grandeur and longevity, only to shock them with the devastation it leaves behind the next. But it is important not to lose sight of the fact that it is always there, lurking in the dark waters of the text. As critics, we must embrace it in order to expose it; this much we owe to the society at large because: "Criticism cannot assume that its province is merely the text, not even the great literary text. It must see itself, with other discourse, inhabiting a much contested cultural space, in which what has counted in the continuity and transmission of knowledge has been the signifier, as an event that has left lasting traces upon the human subject." (Said 1983: 225) We would not agree with the statement that Tom Crick shies away from Empire and that the Fenlands are his microcosm. (Đerić 2015: 71; 94) With his dominating nature and sharp eye, he is fully immersed in all that Empire is. It has been said that some stories are told because of something the narrator wanted to keep quiet about or at least forget, and Tom's story is one of those stories (Đerić 2015: 99 citing Paunović 2006: 168), but to this we would add that perhaps it is the story of Britain's imperial past and its implications and legacy that Swift wanted to address in this novel in order to keep quiet about them or to forget them through his character Tom Crick.

Finally, due to the versatile role that Empire plays in Waterland, both because of the position it takes up between a glorious, imperial past and a gloomy, postcolonial future, and its constant rotation between fact and fiction, perhaps the best location to place and examine this novel in is Homi Bhabha's Third Space. As Pamela Cooper put it: "If we read the configurations of landscape in Waterland through Bhabha's spatial formulations of alterity, the Fens (and by extension their closest human analogue, the phlegmatic and amphibious Dick) become the terrain of hybridity; the marsh simultaneously fixes and dissolves the frontiers of its own conquest under the aegis of imperialism." (1996: 383) Furthermore, the binary oppositions of water and land present in the novel's title "are 
caught within a mutually negating tension that threatens ultimately to propel both into non-meaning in the search for a fixed referent" (Lea 2005: 81) but they cannot exist one without the other. As a postmodern novel, Waterland does not have to have fixed referents, it is important to examine all their possible combinations, and we have mentioned a few in this paper. Silt, on the other hand, does not have a binary opposite and exists as a "free-floating signifier" which "seems to occupy a third space outside binary definition" and "is integral, therefore, both to the novel's symbolisation and to the undermining of those same symbols". (Lea 2005: 81-82) Dick controls the silt, so he controls the Third Space. If he could be taken to represent Empire, all falls into place. In other words, the postmodern nothingness of doubt is juxtaposed with an outwardly glorious colonial legacy, and these binary oppositions will forever be circling the Third Space, haunted by images of Empire. For some, the story of Waterland will always be oppressing, while for others it will be liberating.

\section{References}

Bentley, N. (2008). Contemporary British Fiction. Edinburgh: Edinburgh University Press.

Bernard, C. (1991). Graham Swift: la parole chronique. Nouveaux échos de la fiction britannique. Nancy: Presses universitaires de Nancy.

Bradbury, M. (2001). The Modern British Novel 1878-2001. London: Penguin.

Cooper, P. (2002). Graham Swift's Last Orders. A Reader's Guide. New York, London: Continuum.

---. (1996). Imperial Topographies: the Spaces of History in Waterland. MFS Modern Fiction Studies, Volume 42, Number 2, Summer 1996, 371-396.

Cowley, M. (ed.) (1965). Writers at Work: The Paris Review Interviews. New York: The Viking Press.

Craps, S. (2009). An Interview with Graham Swift. Contemporary Literature Volume 50 Number 4, Winter 2009, 637-661.

---. (2005). Trauma and Ethics in the Novels of Graham Swift: No Short-Cuts to Salvation. Brighton/Portland: Sussex Academic Press. 
Đerić, B. (2015). "Naratori i naracija u romanima Grejama Svifta" ["Narrators and Narration in Graham Swift's Novels"]. Doctoral dissertation, Faculty of Philosophy, University of Novi Sad.

Gallix, F. (2003). Écrire l'imagination. Bordeaux: Presses universitaires.

Gledić, B. (2018). "Hibridni identitet u romanima Grejama Svifta i Hanifa Kurejšija" ["Hybrid Identity in Novels by Graham Swift and Hanif Kureishi"]. Doctoral dissertation, Faculty of Philology, University of Belgrade.

Gledić, B. (2016). Transformation of Britishness - Graham Swift as a Postcolonial Storyteller. BELLS - Belgrade English Language and Literature Studies, volume VIII, 319-330.

Hall, S. (2000). The Question of Cultural Identity. In: S. Hall et al. (eds.), Modernity: An Introduction to Modern Societies, Oxford: Blackwell Publishers Ltd, 595-634.

Hutcheon, L. (1991). The Politics of Postmodernism. New York \& London: Routledge.

---. (1988). A Poetics of Postmodernism - History, Theory, Fiction, New York/ London: Routledge.

Jain, J. (2010). From Encounters to Introspection: Negotiating Cultural Pasts. Indian Literature, Vol. 54, No. 6 (260) (November/December 2010), 134-141.

Jenkins, K. (2009). Re-thinking History. London and New York: Routledge. Jovanović, A. V. (2012). Glasovi i tišine u kritičkom diskursu o britanskoj književnosti dvadesetog veka. Beograd: Mono i Manjana.

Lea, D. (2005). Graham Swift. Manchester: Manchester University Press. Malcolm, D. (2003). Understanding Graham Swift. South Carolina: University of South Carolina Press.

McHale, B. (1987). Postmodernist Fiction. London: Methuen.

Meneses, J. (2017). Historical Restoration, Narrative Agency, and Silence in Graham Swift's Waterland. Journal of Modern Literature, Volume 40, Number 3, Spring 2017, 135-152.

Morel, M. (ed.) (1996). Graham Swift ou le temps du récit. Paris: Messene. Orr, A. (2016). Bodily Fluids: Female Corporeality as Neo-Victorian Agency in Graham Swift's Waterland. Australasian Journal of Victorian Studies 21.1, 85-93.

Paunović, Z. (2006). Istorija, fikcija, mit. Eseji o angloameričkoj književnosti. Beograd: Geopoetika.

Said, E. W. (1994). Culture and Imperialism. London: Vintage. 
---. (1983). The World, The Text and the Critic. Cambridge, MA: Harvard University Press.

Schad, J. (1992). The End of the End of History: Graham Swift's Waterland. MFS Modern Fiction Studies, Volume 38, Number 4, Winter 1992, 911-925.

Swift, G. (2009). Making an Elephant. Writing from Within. London: Picador.

---. (1984). Waterland. London: Picador.

Tollance, P. (2011). La scène da la voix. Villeneuve d'Ascq, France: Presses Universitaires du Septentrion.

White, H. (1978). Tropics of Discourse: Essays in Cultural Criticism. Baltimore and London: The Johns Hopkins University Press.

Widdowson, P. (2006). Graham Swift. United Kingdom: Northcote House Publishers, Ltd.

Received: 1 December 2018

Accepted for publication: 28 December 2018

Бојана Гледић

ЛИЦА ИМПЕРИЈЕ У МОЧВАРИ ГРЕЈАМА СВИФТА

\section{Сажетак}

Поред чињенице да представља најпознатије дело Грејама Свифта и вероватно један од најцењенијих британских романа осамдесетих година прошлог века, многи критичари Мочвару сматрају отеловљењем постмодернистичког романа. Линда Хачн је искористила пример овог романа да би приказала оно што је дефинисала као „историјску метафикцију“, и када човек помисли на овај роман то обично бива у контексту историје и њене улоге у животу обичног човека. Оно што је интересантно јесте чињеница да на први поглед и читаоцу и критичару може промаћи о каквој врсти историје Грејам Свифт говори у овом роману. Када се роман подробније испита, међутим, не може се избећи сусрет са империјалним које вреба испод површине. Из наведеног разлога, овај рад бави се вишеструком улогом империјалног у историји каквом је види Том Крик.

Кључне речи: Мочвара, империја, Грејам Свифт, постколонијално, постмодерно 